\title{
Caffeine Formation by Suspension Cultures of Coffea dewevrei
}

\author{
Rosana Mary Sartor and Paulo Mazzafera* \\ Departamento de Fisiologia Vegetal, Instituto de Biologia, CP 6109, Universidade Estadual de Campinas, \\ 13083-970, Campinas, SP, Brazil
}

\begin{abstract}
The low caffeine content in leaves of $C$. dewevrei $(\sim 0.5 \mathrm{mg} / \mathrm{g})$ is due to a low biosynthesis associated with a fast degradation. On the other hand, high biosynthesis and low degradation confer a higher content $(\sim 8 \mathrm{mg} / \mathrm{g})$ in leaves of $C$. arabica. In this work it was observed that cell cultures of $C$. dewevrei recovered the ability to synthesize caffeine almost in similar levels of $C$. arabica cultures. Tracer experiments with labelled carbon dioxide showed a significant accumulation of radioactivity in caffeine and metabolites, indicating an active biosynthesis. When the cultures were fed with labelled caffeine most of the radioactivity was recovered in caffeine, indicating that although active, degradation was not so efficient as in leaves, and therefore, contributing for the alkaloid accumulation in the cell cultures.
\end{abstract}

Key words: Coffee; caffeine, cell suspension culture; methylxanthines

\section{INTRODUCTION}

Many secondary metabolites have economic importance since they have pharmaceutical / medical properties and several are used in the food industry. Consequently, the possibility of using large fermenter units (bioreactors) to grow plant cells stimulated several investigations aimed at the commercial production of valuable secondary metabolites (Brodelius et al., 1979). However, because the low productivity when compared with the concentrations in the plant tissues, a few successful examples can be cited, the most known, the production of shikonin by cell suspension of Lithospermum erythrorizhon. Nevertheless, the advantage of easy-handling and the possibility to alter growth conditions, such as temperature, light and media composition, make cell culture a powerful tool to investigate the metabolism of secondary metabolites and its modulation by enzymes (Zenk, 1991).

Caffeine (1,3,7-trimethylxanthine) production by cultured coffee cells followed the same fashion, from the bioreactors large scale production (Prenosil et al., 1987) up to its use for a better understanding of the metabolism (Baumann et al., 1983; Baumann \& Röhrig, 1989;
Frischknecht \& Baumann, 1985; Schulthess \& Baumann, 1995).

C. arabica was the coffee species used for most studies on caffeine metabolism in intact tissues (Suzuki et al., 1992) and from these studies it was suggested that the main metabolic pathway might follow the pathway shown in the Fig 1.

Caffeine is slowly degraded in C. arabica tissues. However, tracer experiments with labelled caffeine showed that the degradation rate was significantly higher in other coffee species, particularly in $C$. dewevrei. Comparative studies using both species showed that caffeine concentration was controlled by the ratio between biosynthesis e degradation, which could vary during the fruit maturation. In addition, it was also observed that an alternative route for caffeine demethylation via theobromine was more effective in C. dewevrei (Mazzafera et al., 1991; Mazzafera et al., 1994).

A very limited number of studies using tissue culture or cell suspension were carried out with other coffee species than $C$. arabica. $C$. canephora was used mostly in studies aiming at plant micropropagation (Monaco et al., 1977;

Author for correspondence 
Söndahl \& Loh, 1988; Söndahl et al., 1984). Tissue cultures of orthotropic shoots, embryos and seed perisperm were developed, respectively, with $C$. liberica, $C$. dewevrei and C. stenophylla (Colonna, 1972; Monaco et al., 1977; Staritsky, 1970). To our knowledge there is only one report in the literature where other coffee species and caffeine production were investigated using cell cultures (Baumann \& Frischknecht, 1988). However, none of them was C. dewevrei. Therefore, in this study the caffeine production and its metabolism were investigated in cell cultures of $C$. dewevrei.

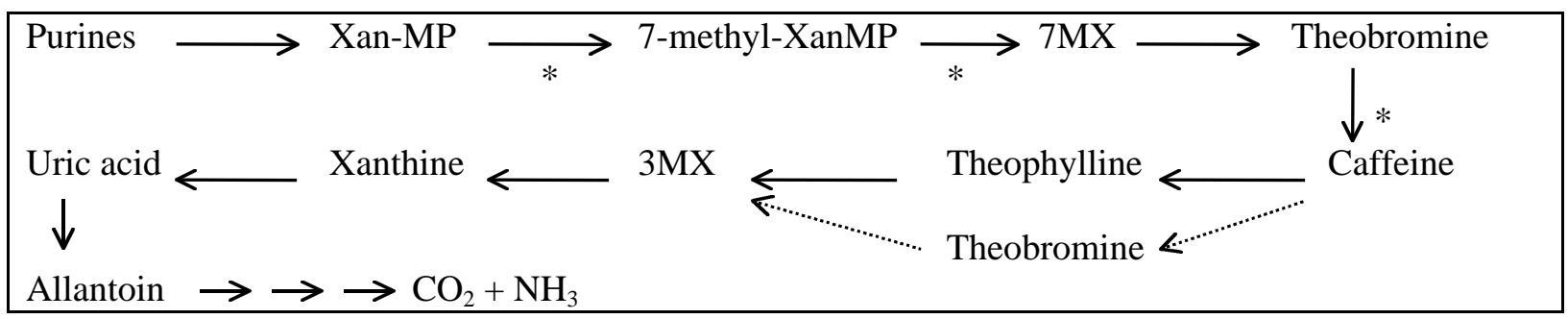

Figure 1. Caffeine metabolic pathway in coffee. Xan-MP = xanthosine-mono-phosphate; 7MX = 7-methylxanthine; Theobromine $=3,7$-dimethylxanthine; Theophylline $=1,3$-dimethylxanthine, $3 \mathrm{MX}=3$-methylxanthine The asterisks indicate the steps where methyltransferases transfer methyl groups from S-adenosylmethionine to caffeine precursors. The dashed lines indicate an alternative pathways.

\section{MATERIALS AND METHODS}

Plant material and cell suspension cultures: Plants of $C$. dewevrei and $C$. arabica growing outdoors were used as explant source. Friable calli were obtained from leaves applying the protocol of Söndahl et al. (1984). Using a forceps, calli permanently maintained in the dark were carefully divided in small aggregates before inoculation to facilitate the cell dispersion in the medium. The composition of the liquid medium was the same as the solid medium for calli cultivation, except agar. The erlenmeyers (250 $\mathrm{mL})$ containing the medium $(50 \mathrm{~mL})$ were weighed before and after inoculation in order to determine the initial mass of cells per flask, which averaged between 0.3 and $0.6 \mathrm{~g}$. The inoculated flasks were kept in an orbital shaker $(120 \mathrm{rpm})$, at $28^{\circ} \mathrm{C}$, under constant light provided by two $40 \mathrm{~W}$ incandescent bulbs positioned 30 $\mathrm{cm}$ from the top of the flasks. In the experiments where theobromine was added to the cell suspensions, the addition was made before sterilisation of the medium in autoclave. At the samplings the cells were recovered by filtration under vacuum and the filter paper holding the cells was dried in Petri dishes at $80^{\circ} \mathrm{C}$ for two days. Since the filter papers had been previously weighed, the difference before and after filtration gave the dry weight of the cells. Samplings were made just after inoculation (day 0) and the data used to calculate the growth rate of the next samplings at days $1,7,14,21,28,35$ and 42 . The dried cells and aliquots of the filtered medium were reserved in silica gel and at $-20^{\circ} \mathrm{C}$, respectively, for the alkaloid analysis. Four replicates were made for each sampling.

Caffeine and chlorogenic acid determinations: Caffeine and chlorogenic acid (5-caffeoylquinic acid) concentrations were determined in the leaves used as explants by reversed-phase high-performance liquid chromatography (RP-HPLC) (Mazzafera, 1997; Mazzafera et al., 1991). The dried cells $(50 \mathrm{mg})$ were extracted with $1-\mathrm{mL}$ of $70 \%$ methanol in cap sealed tubes for $2 \mathrm{~h}$ in a boiling water bath. After cooling, 200$\mu \mathrm{L}$ of the Carrez reagent were added (Clifford \& Ramirez-Martinez, 1990), vortexed and the mixture transferred to Eppendorf tubes. After centrifugation at $15,000 \mathrm{rpm}$ in a bench top centrifuge the supernatant was diluted to $15 \%$ methanol with distilled water, filtered in $0.22-\mu \mathrm{m}$ membrane and reserved for analysis by RP-HPLC as above. For the analysis of caffeine in the medium aliquots were filtered and directly injected in the HPLC. 
Radioisotope feeding experiments: Cell suspension cultures of $C$. dewevrei were produced as previously indicated. At the inoculation day cells of 6 flasks were collected in order to determine the initial dry mass. After 10 days of cultivation six flasks received $\left[2-{ }^{14} \mathrm{C}\right]$ caffeine (specific activity $10 \mu \mathrm{Ci} / \mathrm{mmol}$ ) or $\mathrm{Ba}^{14} \mathrm{CO}_{3}$ (specific activity $55 \mathrm{mCi} / \mathrm{mmol}$ ). Labelled caffeine was obtained by methylation of $\left[2-{ }^{14} \mathrm{C}\right]$ xanthine (specific activity $50 \mathrm{mCi} / \mathrm{mmol}$ ) (Heftmann, 1971). The flasks received 370,000 of caffeine or $530,000 \mathrm{cpm}$ of barium carbonate, respectively. The labelled compounds were diluted in 2-mL of distilled water and filtered in $0.22-\mu \mathrm{m}$ sterile filters before addition. Just before addition, the $\mathrm{pH}$ of the medium in the flasks was adjusted to 6.5 with sterile $0.1 \mathrm{~mol} / \mathrm{L} \mathrm{NaOH}$. Six flasks that did not receive any addition were used as controls for dry matter determination. The cells were cultured for further ten days and harvested as described before. However, after filtration the medium was reserved and the cells were washed several times with distilled water. The cells were dried and caffeine and metabolites extraction was carried out as described before. The medium was lyophilized, dissolved in $5 \mathrm{~mL}$ of distilled water, filtered in $0,22 \mu \mathrm{m}$ filters and kept at $-20^{\circ} \mathrm{C}$ until analysis. Caffeine and metabolites were separated in the medium and cell extracts by RP-HPLC (Berthou et al., 1992). Before injection, the samples were mixed with aqueous solution containing $5 \mu \mathrm{g}$ of caffeine, theobromine, theophylline, araxanthine (1,7-dimethylxanthine), 1-methylxanthine, 3-methylxanthine, 7-methylxanthine, 1,3-dimethyluric acid, 1,7-dimethyluric acid, 3,7-dimethyluric acid, xanthine and uric acid. The separation was monitored at $280 \mathrm{~nm}$ and at elution, observed by the peaks registered in a chart recorder; the compounds were collected in scintillation vials, dried at $60^{\circ} \mathrm{C}$ and the radioactivity determined in a scintillation counter. In this experiment the endogenous levels of caffeine were not determined.

\section{RESULTS AND DISCUSSION}

White and very friable calli were obtained from leaf explants maintained in the dark. Before inoculation in the liquid medium they were divided in cell aggregates with size between 0.5 and $1 \mathrm{~cm}$. Once transferred to the liquid medium the aggregates became smaller due to agitation in the orbital shaker. During the cultivation period, the increase of dry mass of $C$. dewevrei cells was always lower than for C. arabica cells (Fig. 2A). A possible reason for this might be that the medium composition was not so adequate for this species as for $C$. arabica (Baumann \& Frischknecht, 1988; Monaco et al., 1977; Söndahl \& Loh, 1988).

Dry matter accumulation during the cell growth of $C$. arabica culture follows a sigmoidal curve type (Baumann \& Frischknecht, 1988; Baumann \& Röhrig, 1989; Frischknecht \& Baumann, 1980; Kurata et al., 1990; Townsley, 1974). Here, until the $42^{\text {nd }}$ day the cells of both species have not reached the stationary phase (Fig. 2A). However, in these previous works the proportion between inoculum and liquid medium was much higher than the one used here. Consequently, the stationary phase was reached in less than 21 days. In addition, the inoculum was sampled from on going cell cultures, what could have avoid any sort of physiological stress. In any case, the continuous growth observed here indicates that nutrients were not suppressing cell growth. It was not observed any browning of the cultures what would be indicative of cell death.

The caffeine contents in the leaves used as explants for the tissue culture are in agreement with previous reports (Mazzafera, 1993; Mazzafera et al., 1991; Mazzafera \& Magalhães, 1991). Caffeine content in C. arabica was $9.29 \mathrm{mg} / \mathrm{g}$ and $0.46 \mathrm{mg} / \mathrm{g}$ in $C$. dewevrei. The chlorogenic acid contents were $5.64 \mathrm{mg} / \mathrm{g}$ and $16.78 \mathrm{mg} / \mathrm{g}$, respectively. Baumann et al. (1991) detected $4.55 \mathrm{mg} / \mathrm{g}$ of chlorogenic acid in leaves of $C$. arabica.

On average, the dry weight of cells per flask varied between 0.06 to $0.25 \mathrm{~g}$ during the samplings. Therefore, comparing the caffeine concentration in the dryed cells (Fig. 2B) and in the medium (Fig. 2C) it is clear that most of the alkaloid was released in the medium (Figs 2B and C). Calculating the total caffeine in the flask (entire cell mass + medium - data not shown) the amount per cell dry mass was much lower than the values detected in leaves. For $C$. arabica the values varied from $0.3 \mathrm{mg} / \mathrm{g}$ (21 days) up to 1.9 $\mathrm{mg} / \mathrm{g}$ (28 days). Comparatively, these values are 
in agreement with previous reports with the same species. Frischknecht \& Baumann (1980), Baumann \& Frischknecht (1988) and Baumann \& Röhrig (1989) observed in cultures under photoperiod caffeine yields between 0.2 and 10 $\mathrm{mg} / \mathrm{g}$.

Other authors presented their data as amount of caffeine per volume and obtained values of 2.6 to
200 mg (Baumann \& Röhrig, 1989; Frischknecht \& Baumann, 1985; Kurata et al., 1990). In this work, the calculation of total caffeine per litre gave $4.3 \mathrm{mg}$ as the highest value, observed with C. arabica at 28 days of cultivation (data not shown). As suggested for cell growth, the low concentrations observed here probably were due to the proportion of the cell mass and medium volume.
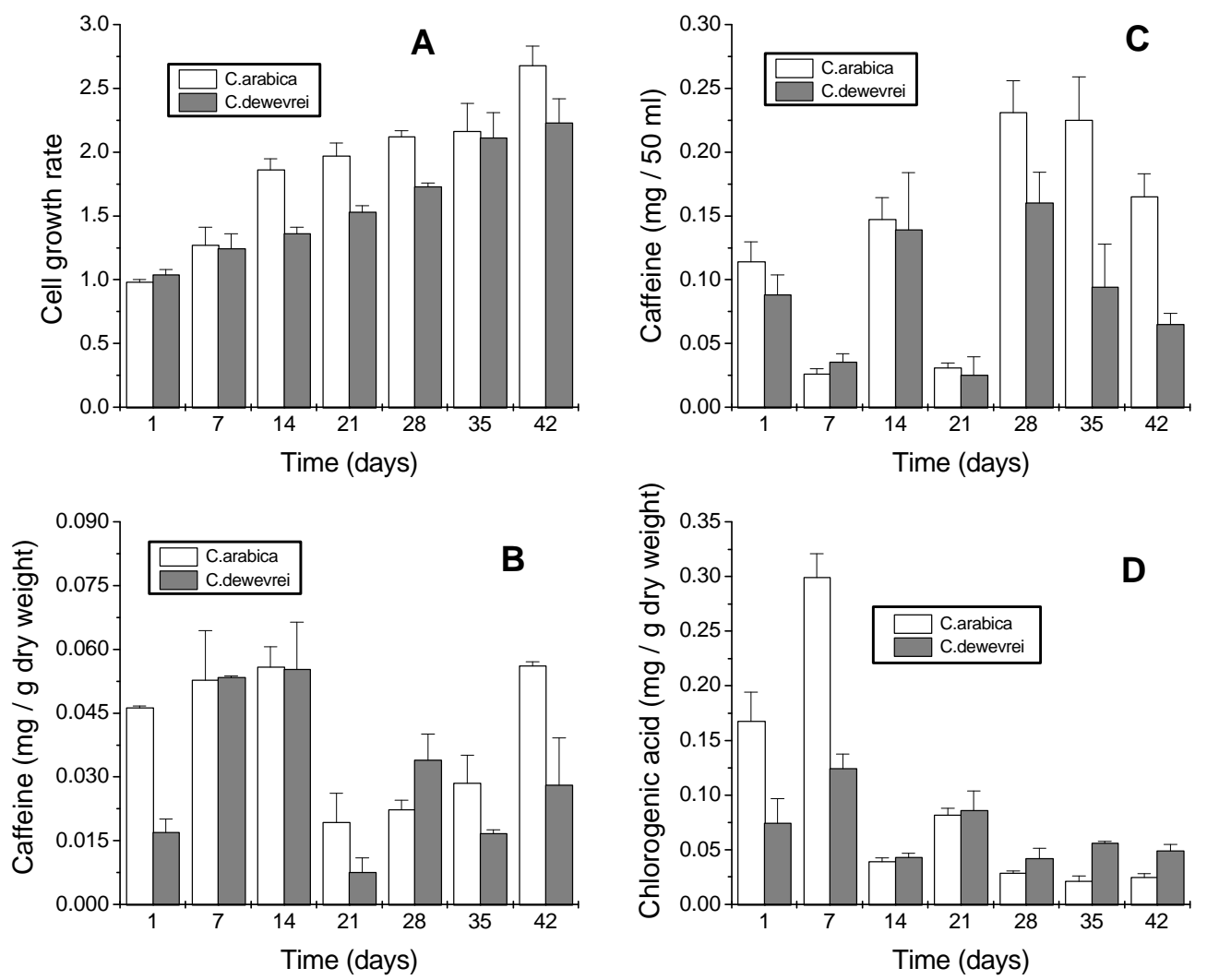

Figure 2. Cell growth - final/initial cell dry weight (A), caffeine concentration in the cells (B) and medium (C), and chlorogenic acid in the cells (D). Means of four replicates. Bars indicate standard errors.

As well as for cell growth, caffeine accumulation has been reported to follow a sigmoidal curve (Baumann \& Frischknecht, 1988; Baumann \& Röhrig, 1989; Frischknecht \& Baumann, 1980; Kurata et al., 1990; Townsley, 1974). Here it was observed a peak of caffeine production at 7 and 14 days of cultivation, with reduction and a further increase up to the end of the experiment (Fig. 2B). A similar alkaloid accumulation was observed by Buckland \& Townsley (1975) in cell cultures of $C$. arabica. After a decrease, there was accumulation of caffeine in the cells up to 3 to 4 times higher than the initial level. The high values observed here in the first three sampling may be a consequence of stimulation by light (Baumann \& Röhrig, 1989; Frischknecht \& Baumann, 1985; Kurata et al., 1997; Kurata et al., 1990) since calli grown in the dark were used to establish the cell cultures. 
If the caffeine data were plotted as total caffeine (cell mass + medium) per flask or per cell dry mass the pattern observed would be almost the same of that obtained for medium (Fig. 2C), because the amount released in the medium was much higher than in the cells. Therefore, it would be possible to observe two peaks of alkaloid production. Considering the that high values of caffeine in the medium observed in day 1 were a consequence of cell damage provoked by the splitting of calli in small aggregates during the inoculation, consequently, releasing intracellular caffeine, increases of concentrations due to caffeine biosynthesis were in fact observed at days 14 and 28/35. However, this biphasic pattern was not observed in the cells (Fig. 2B). At day 7, in opposition to the medium, there was an increase of caffeine in the cells. In addition, after a decline in day 21, caffeine started to increase up to the end of the experiment. This behaviour seems to be related with the chlorogenic acid concentration in the cells (Fig. 2D). It has been shown that caffeine is retained intracellularly in the vacuoles because its complexation with this phenolic acid (Baumann \& Röhrig, 1989). Therefore, the increase of caffeine in the cells at day 7 probably was a consequence of chlorogenic acid increase, caused by phenylalanine ammonia-lyase induction due to light exposition, since the cultures were established with material maintained in the dark. However, despite the increase of caffeine concentration, in the last three weeks of cultivation there was a stabilization of the chlorogenic acid content. Although the complexation of caffeine and the phenolic acid has been experimentally confirmed, lack of correlation was also observed by other authors. Baumann \& Röhrig (1989) observed that caffeine accumulation followed a sigmoidal curve, while chlorogenic acid accumulated biphasically in cell cultures of $C$. arabica. In their work, chlorogenic acid was detected only in the cell, varying from 12 to $38 \mathrm{mg} / \mathrm{g}$. In this work a tendency of a biphasic curve was also observed, however, the concentration of chlorogenic acid in the cells was lower.

As determined here and by other reports, $C$. dewevrei leaves have less caffeine than $C$. arabica. Tracer feeding experiments using ${ }^{3} \mathrm{H}$ or ${ }^{14} \mathrm{C}$ labelled caffeine and determination of the activities of the methyltransferases involved in the caffeine biosynthesis in these coffee species showed that the low alkaloid concentration in leaves of $C$. dewevrei is due to low biosynthesis activity and fast degradation, while $C$. arabica has high biosynthesis and low degradation (Mazzafera, 1993; Mazzafera et al., 1991; Mazzafera et al., 1994). Consequently, it is interesting to observe that although less than intact tissues, cell cultures of $C$. dewevrei produced relatively high amounts of the alkaloid when compared to $C$. arabica. Therefore, it might be that the ratio between biosynthesis and degradation, or both, were altered in the cell cultures, leading to alkaloid accumulation. In order to investigate these possibilities, experiments were carried out, where theobromine, $\left[2-{ }^{14} \mathrm{C}\right]$ caffeine or $\mathrm{Ba}^{14} \mathrm{CO}_{3}$ were included in cell suspension cultures of $C$. dewevrei.

When theobromine was added to the medium at $40 \mu \mathrm{g} / \mathrm{ml}$ the cell growth was not affected (Fig. $3 \mathrm{~A})$. However, in this experiment the cells were grown up to 49 days and the stationary phase could be seen in both treatments.

Caffeine was estimated in $5 \mathrm{~mL}$ aliquots taken from the cell culture, without separation of cells and medium. The samples were dried at $80^{\circ} \mathrm{C}$ and after addition of $2 \mathrm{~mL}$ of $70 \%$ methanol the extraction proceeded as for the cells in the first experiment. In the control treatment caffeine accumulation was similar to the data of the previous experiment (Fig. 3B). Although the samples of day 7 were lost it was possible to observe that theobromine addition changed the way caffeine accumulated in the culture. The more pronounced changes were the decrease of caffeine in the first samplings and its marked accumulation in the last ones. Induction of caffeine biosynthesis by theobromine addition in cell cultures of $C$. arabica was observed by Frischknecht \& Baumann (1980) and Kurata et al. (1997). The first authors suggested that caffeine production might be limited by the amount of the enzymes of the alkaloid biosynthesis or shortage of substrates (the methyl donor S-adenosylmethionine and purine rings). It was also reported (Baumann et al., 1983) that the time course of the methyltransferases activities did not correlate with the alkaloid accumulation. Kurata et al. (1997) suggested that S-adenosylmethionine would not be a limiting factor in caffeine production. The results 
presented here with $C$. dewevrei indicate that purine rings are indeed the best candidates as limiting factors for caffeine production; however, they also show an efficient methylation of theobromine to caffeine, partially explaining the alkaloid accumulation, as shown in Fig. 3B.

The Fig. $3 \mathrm{C}$ shows that $10.2 \%$ of the radioactivity added as $\mathrm{Ba}^{14} \mathrm{CO}_{3}$ in the cell cultures was recovered as caffeine and its metabolites. This clearly shows a significant allocation of carbon in the caffeine metabolism indicating that cells of $C$. dewevrei in suspension culture recovered the ability to synthesize caffeine. In addition, it seems that the metabolic pathway was also affected since the uric acid form of theobromine, 3,7-dimethyluric acid, accumulated in the cells.
Petermann \& Baumann (1983) observed that 1,3,7,9-tetramethyluric acid, $O(2), 1,9$-trimethyluric acid and $O(2), 1,7,9$-tetramethyluric acid were formed as degradation products of caffeine in the seedlings of $C$. liberica, which is genetically close to $C$. dewevrei. However, these compounds were not detected in cell suspensions of the same coffee specie (Baumann \& Frischknecht, 1988). 3,7-Dimethyluric acid has been found as a caffeine catabolite in Pseudomonas putida and its formation was suggested to be a consequence of a high xanthine oxidase activity (Yamaoka-Yano \& Mazzafera, 1999). In addition, since there was no further degradation of this methyluric acid because uricase substrate-specificity, it was considered as an end product.
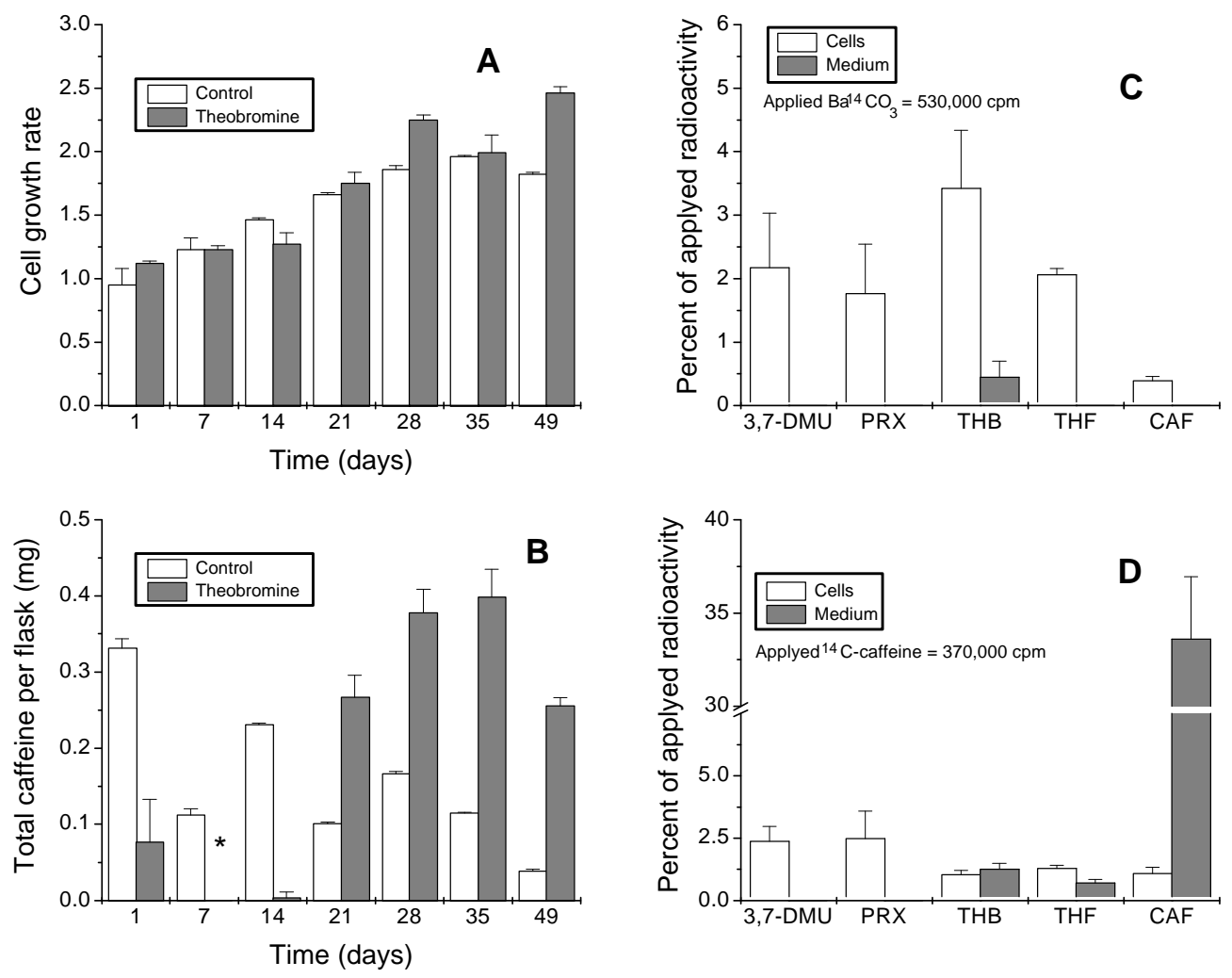

Figure 3. C. dewevrei cell growth - final/initial cell dry mass (A), and total caffeine per flask (B) when theobromine was added to the medium at $40 \mu \mathrm{g} / \mathrm{ml}$; and distribution of radioactivity in caffeine metabolites in cell cultures fed with $\left[2-{ }^{14} \mathrm{C}\right]$ caffeine or $\mathrm{Ba}^{14} \mathrm{CO}_{3}$. Means of four $(\mathrm{A}$ and $\mathrm{B})$ and six replicates $(\mathrm{C}$ and $\mathrm{D})$. Bars indicate standard errors. 3,7$\mathrm{DMU}=3,7$-dimethyluric acid; $\mathrm{PRX}=$ paraxanthine; $\mathrm{THB}=$ theobromine; $\mathrm{THF}=$ theophylline; $\mathrm{CAF}=$ caffeine. $*=$ lost samples. 
Paraxanthine, which is not usually found in intact coffee tissues, was detected here (Fig. 3C). It was also detected in cotyledonary leaves of $C$. arabica (Suzuki et al., 1992) and in cell suspensions of $C$. eugenioides and C. liberica (Baumann \& Frischknecht, 1988)

The same compounds observed to accumulate with $\mathrm{Ba}^{14} \mathrm{CO}_{3}$ were detected when labelled caffeine was added to the cultures (Fig. 3D) and, interestingly, in the cells, caffeine was not the compound holding more radioactivity. Previous reports showed that leaves and fruits of $C$. dewevrei accumulated theobromine even in higher concentration that caffeine (Mazzafera, 1993; Mazzafera et al., 1991; Mazzafera et al., 1994). It seems that besides demethylation to theophylline and 3-methylxanthine as the main catabolic route (cf. Fig. 1), theobromine accumulates as a caffeine demethylation product and it is slowly degraded to 3-methylxanthine. Its re-use as substrate for caffeine biosynthesis would be limited since $C$. dewevrei tissues have low activities of the biosynthesis enzymes. In this work, the accumulation of 3,7-dimethyluric acid supports this conclusion.

Theophylline is not frequently detected in coffee tissues and experiments with the labelled compound showed that it is rapidly degraded (Suzuki et al., 1992). We interpret its low detection here as an indication that caffeine was less efficiently degraded than intact coffee tissue. In addition, approximately $35 \%$ of the radioactivity was recovered as caffeine in the experiment with the labelled alkaloid. Considering the incubation period (10 days), this value is higher than the recoveries observed with leaves and fruits of this species (Mazzafera, 1993; Mazzafera et al., 1991; Mazzafera et al., 1994). Using the specific activity of the labelled product, it was estimated that the caffeine degradation rate was $276 \mu \mathrm{g} / \mathrm{g}$ of cells/day. Baumann \& Frischknecht (1988) estimated 40 $\mu \mathrm{g} / \mathrm{g} / \mathrm{day}$ for $C$. canephora, 75 for C. arabica, 90 for $C$. congensis, and 250 for $C$. eugenioides and C. liberica and 800 for C. humilis. Although higher than $C$. arabica, this rate may not be sufficient to affect the ratio between synthesis and degradation in favour of a lower caffeine content.

\section{ACKNOWLEDGMENTS}

R. M. Sartor and P. Mazzafera thank Fundação de Amparo a Pesquisa do Estado de São Paulo and CNPq - Brazil for an undergraduate fellowship (Proj. 95/6539-9) and a research fellowship, respectively.

\section{RESUMO}

O baixo conteúdo de cafeína em folhas de $C$. dewevrei $(\sim 0.5 \mathrm{mg} / \mathrm{g})$ é devido a uma menor biossíntese associada a uma rápida degradação. Por outro lado, alta taxa de biossíntese e baixa degradação confere o maior conteúdo $(\sim 8 \mathrm{mg} / \mathrm{g})$ em folhas de $C$. arabica. Neste trabalho estudouse a produção de cafeína em culturas de células em suspensão de $C$. dewevrei. Observou-se que culturas desta espécie de café recuperaram a habilidade em sintetizar cafeína, em níveis semelhantes aos de culturas de $C$. arabica. Em experimento em que carbonato de bário contendo carbono marcado foi adicionado ao meio de cultura observou-se expressivo acúmulo de radioatividade em cafeína e seus metabólitos, indicando ativa biossíntese. Quando culturas receberam cafeína marcada, a maior parte da radioatividade recuperada estava neste alcalóide, indicando que a via de degradação não era tão ativa como em tecidos intactos (folhas) para reduzir o teor de cafeína, levando portanto ao seu acúmulo.

\section{REFERENCES}

Baumann, T. W. \& Frischknecht, P. M. (1988). Caffeine: production by plant (Coffea spp.) cell cultures. In: Biotechnology in Agriculture and Forestry. Vol. 4. Medicinal and Aromatic Plants. ed. Y.P.S. Bajaj. Springer Verlag, Heidelberg, pp. 264-281.

Baumann, T. W.; Koetz, R. \& Morath, P. (1983). $N$-Methyltransferase activities in suspension cultures of Coffea arabica L. Plant Cell Rep., 2, 33-35.

Baumann, T. W. \& Röhrig, L. (1989). Formation and intracellular accumulation of caffeine and chlorogenic acid in suspension 
cultures of Coffea arabica. Phytochemistry, 28, 2667-2669.

Berthou, F.; Guillois, B.; Riche, C.; Dreano, Y.; Jacqz-Aigrain, E. \& Beaunes, P. H. (1992). Interspecies variation in caffeine metabolism related to cytochrome P4501A enzymes. Xenobiotica, 22, 671-680.

Brodelius, P.; Deus, B.; Mosbach, K. \& Zenk, M. H. (1979). Immobilized plant cells for the production and transformation of natural products. FEBS Letters, 103, 93-97.

Buckland, E. \& Townsley, P. M. (1975). Coffee cell suspension cultures: caffeine and chlorogenic acid content. J. Inst. Can. Sci. Technol., 8, 164-165.

Clifford, M. N. \& Ramirez-Martinez, J. R. (1990). Chlorogenic acids and purine alkaloids contents of maté (Ilex paraguariensis) leaf and beverage. Food Chemistry, 35, 13-21.

Colonna, J. P. (1972). Contribution a l'étude de la culture in vitro d'embryons de caféiers. Action de la caffeine. Café Cacao Thé, 16, 193-203.

Frischknecht, P. M. \& Baumann, T. W. (1980). The pattern of purine alkaloid formation in suspension cultures of Coffea arabica. Planta Medica, 40, 245-249.

Frischknecht, P. M. \& Baumann, T. W. (1985). Stress induced formation of purine alkaloids in plant tissue culture of Coffea arabica. Phytochemistry, 24, 2255-2257.

Heftmann, E. (1971). Synthesis of caffeine-2- ${ }^{14}$ C. J. Lab. Comp., 7, 463-465.

Kurata, H.; Matsumura, S. \& Furusaki, S. (1997). Light irradiation causes physiological and metabolic changes for purine alkaloid production by a Coffea arabica cell suspension culture. Plant Sci., 123, 197-203.

Kurata, H.; Seki, M.; Furusaki, S. \& Furuya, T. (1990). Effect of light on caffeine production by plant cells of Coffea arabica. Ann. New York Acad. Sci., 613, 538-541.

Mazzafera, P. (1993). 7-Methylxanthine is not involved in caffeine catabolism in Coffea dewevrei. J. Agric. Food Chem., 41, 1541-1543.

Mazzafera, P. (1997). Maté drinking: caffeine and phenolic acid intake. Food Chem., 60, p.67-71.

Mazzafera, P.; Crozier, A. \& Magalhães, A. C. (1991). Caffeine metabolism in Coffea arabica and other species of coffee. Phytochemistry, 30, 3913-3916.

Mazzafera, P.; Crozier, A. \& Sandberg, G. (1994). Studies on the metabolic control of caffeine turnover in developing endosperms and leaves of Coffea arabica and Coffea dewevrei. J. Agric. Food Chem., 42, 14231427.

Mazzafera, P. \& Magalhães, A. C. N. (1991). Cafeína em folhas e sementes de Coffea e Paracoffea. Rev. bras. Bot., 14, 157-160.

Monaco, L. C.; Söndahl, M. R.; Carvalho, A.; Crocomo, O. J. \& Sharp, W. R. (1977). Applications of tissue culture in the improvement of coffee. In: Applied and Fundamental Aspects of Plant Cell, Tissue, and organ culture, eds. J. Reinert, Y.P.S. Bajaj. Springer-Verlag, Heidelberg, pp. 109-129.

Petermann, J. B. \& Baumann, T. W. (1983). Metabolic relations between methylxanthines and methyluric acids in Coffea L. Plant Physiol., 73, 961-964.

Prenosil, J. E.; Hegglin, M.; Baumann, T. W.; Frischknecht, P. M.; Kapeller, A. W.; Brodelius, P. \& Haldimann, D. (1987). Purine alkaloid producing cell cultures: fundamental aspects and possible applications in biotechnology. Enzyme Microb. Technol., 9, 450-458.

Schulthess, B. H. \& Baumann, T. W. (1995). Stimulation of caffeine biosynthesis in suspension-cultured coffee cells and in situ existence of 7-methylxanthosine. Phytochemistry, 38, 1381-1386.

Söndahl, M. R. \& Loh, W. H.-T. (1988). Coffee Biotechnology. In: Coffee. Vol. 4: Agronomy, eds. R.J. Clarke, R. Macrae. Elsevier Applied Science, New York, pp. 235-262.

Söndahl, M. R.; Nakamura, T.; Medina Filho, H. P.; Carvalho, A.; Fazuoli, L. C. \& Costa, W. M. (1984). Coffee. In: Handbook of Plant Cell Culture. Vol 3. Crop Sciences, eds. P.V. Ammirato, D.A. Evans, W.R. Sharp, Y. Yamada. Macmillan Inc., New York, pp. 564-590.

Staritsky, G. (1970). Embryoid formation in callus tissues of coffee. Acta Bot. Neerl., 19, 509-514.

Suzuki, T.; Ashihara, H. \& Waller, G. R. (1992). Purine and purine alkaloid metabolism in Camellia and Coffea plants. Phytochemistry, 31, 2575-2584. 
Townsley, P. M. (1974). Production of coffee from plant cell suspension cultures. J. Inst. Can. Sci. Technol. Aliment., 7, 79-81.

Yamaoka-Yano, D. M. \& Mazzafera, P. (1999). Catabolic pathway of caffeine and purification of a xanthine oxidase responsible for methyluric acid production in Pseudomonas putida L. Rev. Microbiol., in press.
Zenk, M. H. (1991). Chasing the enzymes of secondary metabolism: plant cell cultures as a pot of gold. Phytochemistry, 30, 3861-3863.

Received: March 15, 1999; Revised: May 19, 1999; Accepted: July 21, 1999. 